Revista Destaques Acadêmicos, Lajeado, v. 10, n. 1, 2018. ISSN 2176-3070

DOI: http://dx.doi.org/10.22410/issn.2176-3070.v10i1a2018.1048

http://www.univates.br/revistas

\title{
ANÁLISE E MELHORIA DO PROCESSO DE SERVIÇOS PRESTADOS POR UMA EMPRESA DO RAMO DE OFICINA MECÂNICA
}

\author{
Lillian Valmorbida ${ }^{1}$, Hélio Diedrich ${ }^{2}$
}

Resumo: O aumento visível e considerável da frota de veículos circulando pelo mundo, fez com que a demanda de serviços para este fim aumentasse consideravelmente nos últimos anos. Com isso, empresas do ramo de oficina mecânica tem a necessidade de se adaptar a este mercado visando qualidade na prestação de serviços a seus clientes. Diante disso, melhorias em parte do processo de serviços prestados pela empresa são propostos aos gestores. Na fundamentação teórica, são abordados conceitos da área de gestão de processo, fluxograma, melhoria de processos, método, dentre outros. Os métodos utilizados são classificados como estudo de caso de abordagem qualitativa. Observações foram feitas no local de trabalho, em vários momentos, acompanhando os processos de serviços realizados pela empresa, assim como uma análise criteriosa do mesmo, sugerindo um novo processo, este mais eficiente e eficaz diminuindo processos desnecessários e retrabalhos que demandam tempo prejudicando todo o sistema de atendimento ao cliente e seus subsistemas. Também foram analisados questões como o arranjo físico da empresa propondo um ambiente mais organizado e cômodo tanto para clientes quanto para os colaboradores da mesma. Os gestores se mostraram muito receptivos e interessados no estudo em questão, se propondo a colocar em pratica este estudo.

Palavras-chave: Gestão de Processos. Fluxograma. Análise de Melhoria de Processo.

\section{INTRODUÇÃO}

As empresas familiares como é o caso da empresa em questão, se caracterizam por terem uma sucessão familiar hierárquica. Algumas por serem de pequeno e médio porte, com o passar do tempo acabam tendo um crescimento

1 Bacharel em Administração pela Universidade do Vale do Taquari - Univates, Lajeado/RS. lyllav@hotmail.com

2 Bacharel em Administração (FATES). Mestre em Engenharia de Produção (UFEGS) - Professor de Graduação e Pós Graduação do Universidade do Vale do Taquari - Univates, Lajeado/RS. heliodiedrich@gmail.com 
maior que o esperado pelos gestores, e estes, quando não preparados para tal crescimento, encontram dificuldades na gestão de processos, o que ocasiona falhas nos procedimentos diários da organização.

O estudo detalhado de processos é de suma importância para as organizações, com ele é possível descartar processos desnecessários, diminuir custos, eliminar desperdícios, retrabalhos, falhas, programar com maior precisão as compras de insumos e prestação de serviços, dentre outros. Deste modo, este artigo objetiva a melhoria de processos para que a empresa continue crescendo, se torne mais competitiva e preparada para as mudanças e crescimentos de mercado que vem ocorrendo desde os últimos anos.

Conforme a revista Abril de fevereiro de 2015, onde um estudo referente o aumento da frota de veículos automotores indicou que de 2001 a 2012 houve um aumento de cerca de 24 milhões para 50 milhões de veículos. Outro estudo publicado pelo G1 em março de 2014, indica que dez anos atrás havia cerca de 7,4 habitantes por carro, já em 2014, atingia 4,4 habitantes por carro. Diante deste aumento considerável na frota, há também um aumento de demanda na prestação de serviços para este público, e estas empresas devem estar preparadas para suprir as necessidades deste mercado.

Os gestores destas empresas diante da frequência que os problemas organizacionais ocorrem sentem falta de uma gestão mais eficiente e eficaz em seus processos, que é o caso de uma empresa do ramo de oficina mecânica, empresa familiar que atua na prestação de serviços há cerca de trinta anos situada no Vale do Taquari/RS. Contam com uma equipe de sete colaboradores, sendo que dois deles, pai e filho são os atuais donos da organização. Devido à sucessão hierárquica da mesma, o filho é o atual gerente, responsável pela gestão e serviços de mecânica da empresa. Há também uma secretária e outros auxiliares para os serviços gerais, além de um motorista que é chamado quando necessário.

Trabalham com mecânica de todos os tipos de veículos leves e pesados a diesel, gasolina e álcool, além de serviços de guincho 24 horas. Atendem aproximadamente 15 a 20 veículos por dia em dias normais e nos feriados este numero aumenta consideravelmente. Conforme informações dos responsáveis, esta empresa possui um estoque de aproximadamente 80 mil reais. Atendem pessoa física e jurídica de todas as classes sociais, situados na cidade e nas cidades arredores assim como pessoas que trafegam pela BR 386.

Em visitas realizadas a empresa e conversas informais realizadas com os gestores, constatou-se que os mesmos encontram dificuldades no momento de organizar e repor seus estoques, itens que estão sobrando são encomendados e itens que faltam acabam não encomendando, o que reflete diretamente no momento de dar manutenção nos veículos. Problemas com registro das entradas e saídas de valores de caixa também são enfrentados por ela, pois não contam com nenhum registro financeiro, ou seja, eles não conhecem seus custos e seus lucros. 
Estes problemas que ocorrem devido à falta de registros afetam outras áreas da empresa, pois ocorrem percas de valores, pois não tem como comprovar que o serviço foi realizado ao cliente, em alguns casos também percas por não saber exatamente em que momento que a garantia de determinada peça colocada no veículo expirou, ocasionando na perca por parte da empresa, pois a mesma fornece ao cliente os serviços sem custo. Devido à centralização de atividades que exigem decisões, tudo tem que passar pelo dono da empresa, o que dificulta nos momentos que ele não está no local.

Visivelmente verificou-se também no local de trabalho problemas com organização tanto de estoque quanto no arranjo físico da organização, além de um layout inadequado para este tipo de serviço prestado pela empresa. $\mathrm{O}$ bem estar de todos que fazem parte do processo também devem ser levado em consideração, pois além de ser um trabalho cansativo, ele submete o trabalhador a uma jornada de trabalho extensa.

Este estudo apresenta uma análise crítica detalhada do processo de serviços prestados pela empresa, seguindo da aplicação de ferramentas para identificar e propor melhorias à organização.

Diante do exposto, o presente estudo pretende responder a seguinte questão: quais ações devem ser empregadas ou adaptadas para melhorar parte dos processos de serviços prestado pela empresa em questão? Este trabalho tem como objetivo geral propor melhorias para parte dos processos de serviços prestados pela empresa. Como objetivos específicos, objetiva-se: (1) Analisar parte dos processos atuais da empresa, identificando possíveis melhorias; (2) Elaborar o fluxograma detalhado e a descrição do processo atual da empresa; (3) Apresentar o novo fluxograma através das possíveis melhorias e descrição das possíveis melhorias; (4) Elaborar quadro contendo os problemas atuais e possíveis melhorias.

\section{FUNDAMENTAÇÃO TEÓRICA}

Neste capítulo, são abordados conceitos e autores da área de gestão de processos, fluxograma de processos, análise e melhoria de processos, 5S, estudo do trabalho dentre outros, com o objetivo de embasar e sustentar teoricamente este estudo.

A gestão de processos quando aplicada, é uma forma de acabar com hábitos e costumes presentes no dia-a-dia das organizações (DE SORDI, 2009). Ela é uma ferramenta gerencial que permite aos gestores eliminar custos indiretos que se acumulam e não agregam valor a empresa. Utilizando esta gestão, é possível que os processos organizacionais funcionem de maneira coerente e com o melhor nível de desempenho que esta gestão é capaz de oferecer. Ela também identifica quando um processo necessita ser substituído por não atender mais as necessidades da empresa e dos clientes. Os benefícios gerados por esta gestão se traduzem em custos mais baixos e maior satisfação 
dos clientes, que leva a empresa a um melhor desempenho organizacional (BROCKE, ROSEMANN, 2013).

As organizações convencionais só percebem as mudanças do ambiente quando são afetadas pelas mesmas e não contam com mecanismos para reagir a tal situação. Reagir a rápidas mudanças que o ambiente proporciona é uma das possibilidades oferecida pela gestão de processos, acrescentam os autores.

Ao implantar esta gestão, algumas atividades como projetar processos a serem realizados e analisar qual a melhor forma de realizá-los passam a ser realizados diariamente pela organização, com o objetivo de melhorar os processos rotineiros (PAIM, CARDOSO, CAULLIRAUX, 2009).

Para melhorar estes processos a análise e melhoria de processos devem ser realizadas, ela é de grande importância para que os processos organizacionais se desenvolvam e para que levem as empresas a excelência gerencial. Ela é realizada através da análise do mapeamento dos processos, visando a melhoria e o redesenho dos mesmos. Este estudo permite estruturar uma sequência de trabalho a ser realizado, analisando, aperfeiçoando e simplificando os processos, além de tratar de maneira adequada os problemas, proporcionando qualidade nos procedimentos (OLIVER, 2010).

Segundo ele, ao projetar o processo, deve-se lavar em conta as necessidades, requisitos e perspectivas dos clientes para que os resultados do processo atendam as expectativas dos mesmos. Muitas vezes, a melhoria de processos não tinge os resultados desejados, mas é de grande importância que a persistência continue para que em algum momento os resultados sejam atingidos.

Para Lucinda (2010), a análise e melhoria de processos identifica os processos que não estão funcionando como deveriam e estão prejudicando a organização. Devem ser seguidos sete passos para realiza-los: mapeamento dos processos organizacionais e dos seus inter-relacionamentos, ele consiste na visão clara que o analista deve ter com todos os processos e os seus interrelacionamentos, todos devem ser mapeados. Identificar fornecedores e clientes da empresa é o melhor ponto para se começar o mapeamento, a partir deles, verifica-se as atividades desenvolvidas, assim como os processos realizados.

O segundo passo consiste na identificação dos processos a serem melhorados. "Neste caso, deverão ser identificados todos os processos que possuem alguma relação com o problema" (LUCINDA, 2010, p. 40).

Na etapa três, é o momento de desenhar o processo, ferramentas como o fluxograma de processos são utilizadas para detalhar os processos. Validar o desenho junto aos interessados, ou seja, apresentar o fluxograma aos membros do processo, se estes discordarem, refazê-lo até que todos estejam de acordo. A análise do processo atual a ser melhorado consiste, conforme o autor, em entender todo o funcionamento do processo e depois detalhá-lo para obter um conhecimento maior. 
Na quarta etapa é o momento de identificar as oportunidades de melhorias, com o uso das ferramentas como a citada anteriormente, é possível a visualização de melhorias a serem implementadas. Seguindo na próxima etapa, deve-se redesenhar o processo e documentá-lo, elaborar o novo fluxograma contendo as melhorias a serem implantadas e documentá-las (LUCINDA, 2010).

Na sexta etapa segundo ele, a implantação do novo processo deve ser feito, este é o momento mais crítico da operação, ele deve ser bem acompanhado para que nada se perca deste processo. A última etapa consiste no acompanhamento do novo processo, ou seja, se não houver este acompanhamento, a tendência é que as coisas retornem ao seu ponto inicial, pois os indivíduos naturalmente tendem a voltar a sua zona de conforto. Acompanhar todos os resultados, incentivando o uso do novo processo, corrigindo-os quando necessário, fazendo o possível para que ele não retorne ao seu ponto inicial.

A melhoria de processos como citado anteriormente, consiste em tornar os processos mais rápidos, através da modernização, simplificação, redução e correção dos mesmos continuamente (STADLER, 2013).

Paim, Cardoso e Caulliraux (2009), dizem que melhorar os processos é responder as mudanças que ocorrem no meio em que a empresa está inserida, através de ações básicas para que ela mantenha seu sistema produtivo competitivo.

Para melhorar o processo, o mapeamento de processos deve ser realizado, este consiste na representação visual dos processos realizados pela empresa. Ele é feito a partir de entrevistas e questionários realizados com os colaboradores e, a partir destas informações, são analisadas a forma como são reunidos em processos e como se relacionam. Para mapear estes processos é necessário identificar o objetivo do processo, dos clientes, fornecedores e resultados esperados; é necessário a documentação do processo, e também, transferir as informações para um mapa visual, ou seja, um fluxograma de processo (STADLER, 2013).

O fluxograma tem o objetivo de mapear o estado dos atuais processos da empresa, representados visivelmente, podendo assim ser analisados por vários ângulos, acrescenta ele.

Na Figura 1 é apresentado um exemplo de fluxograma de processos utilizado para mapear os processos organizacionais desenvolvido com o software BizAgi Process Modeler. 
Figura 1 - Fluxograma desenvolvido no software BizAgi Process Modeler

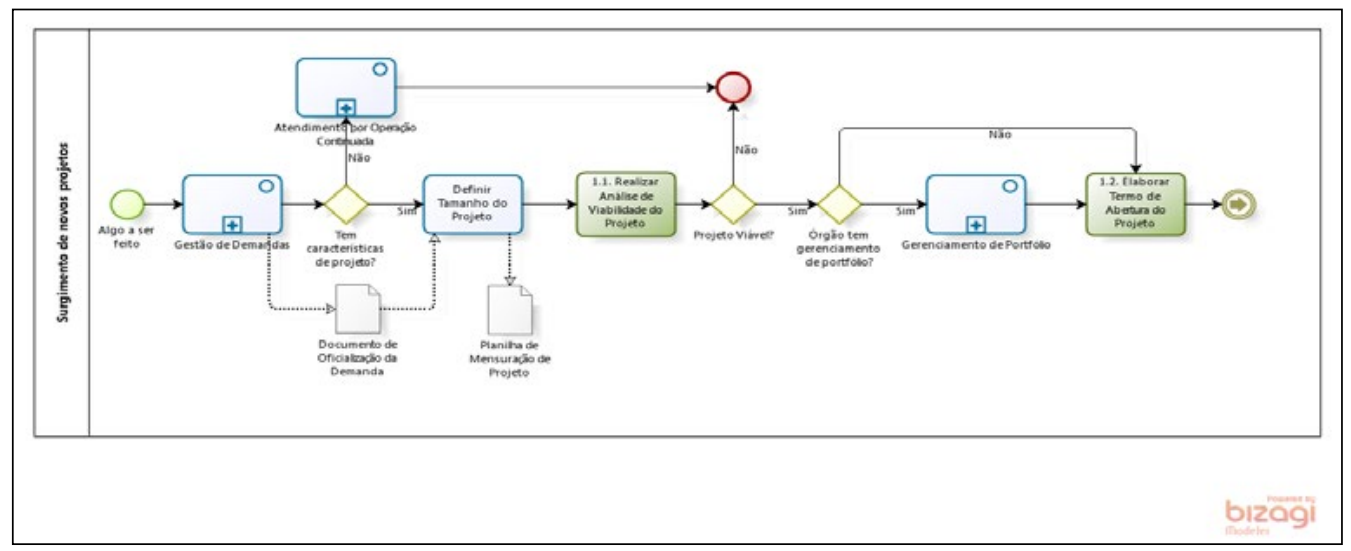

Fonte: SISP, 2014 (surgimento de novos projetos).

Para Custodio (2015), o fluxograma descreve as ações de um processo graficamente e sequencialmente através de símbolos básicos. Com ele, são possíveis de se fazer fáceis análises, abordagem de situações atuais, propostas de novas situações a serem implantadas e melhorar processos presentes.

Na Figura 2 são apresentados os principais elementos utilizados na composição do fluxograma de processos através do software BizAgi Process Modeler. 
Figura 2 - Elementos da notação utilizados na modelagem de processos

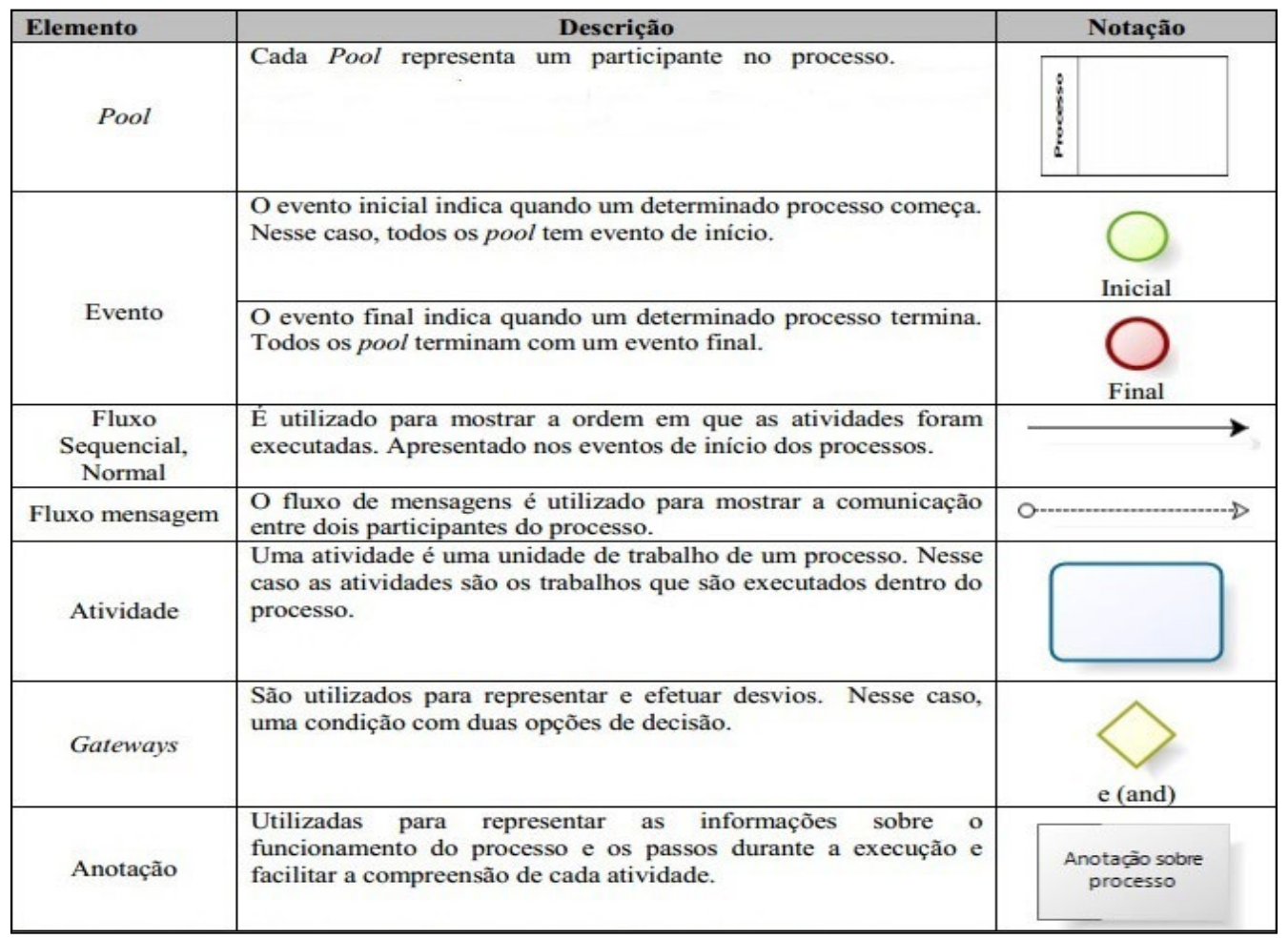

Fonte: Adaptado por Pereira (2011, p. 52).

A gestão de processos abrange também questões como arranjo físico da empresa, ergonomia nos processos produtivos, influência das cores no ambiente de trabalho, dentre outros.

O arranjo físico, conforme comentado no início deste estudo, é chamado também de layout e diz respeito ao espaço físico que a empresa ocupa e a disposição dos equipamentos e máquinas de trabalho necessário para a produção de produtos ou serviços. Tudo que está ligado à produção se denomina arranjo físico (CHIAVENATO, 2005).

Conforme ele, tudo deve estar em local adequado para facilitar o processo produtivo em uma combinação de três fatores denominados como operação das máquinas, produtividade do trabalho e fluxo de materiais, estes três devem estar funcionando na melhor combinação possível.

Para Vieira (1976), o estudo do layout é necessário quando as instalações não são mais eficientes, há necessidade de redução de custos, variação de demanda, ambiente de trabalho inadequado, com muito barulho, temperaturas anormais, iluminação precária, baixo rendimento do trabalho, excesso de 
estoques, muitos manuseios de materiais, dentre outros. Ele deve ser planejado conforme as necessidades da empresa.

Para Marques (1994), ao projetar um layout devem-se levar em conta as possíveis mudanças futuras que poderão ocorrer, tanto diminuição quanto aumento do mesmo. Alguns princípios devem ser estabelecidos: o principio da economia e do movimento diz que o ideal é que o layout tenha a menor distância possível a ser percorrida entre pessoas, ferramentas e operações de fabricação.

"Princípio do fluxo progressivo - O movimento ininterrupto de uma operação para a próxima, sem transportes de volta ou cruzamento de materiais, homens e equipamentos, é o preferível" (MARQUES, 1994, p. 51). O princípio da flexibilidade diz a respeito da possibilidade de adaptação arranjo físico conforme as necessidades de mudança de produtos, volumes de produção, equipamentos e processos, conforme ele. O "princípio da integração - A integração entre os fatores é necessária para que o arranjo físico seja ótimo, deve ser sempre preferida" (MARQUES, 1994, p. 51).

A gestão de estoques que também comentada no inicio deste estudo, tem o propósito de garantir que os produtos estejam disponíveis com o menor nível de itens possível, diminuindo as necessidades de capital investido. A política de administração de capital de estoque deve ser definida pela organização selecionando padrões a serem seguidos pelos gestores.

Níveis de estoques devem ser calculados conforme as necessidades da empresa. O estoque mínimo segundo Santos (2012, p. 131), "é a menor quantidade de material a ser mantida em estoque capaz de atender a um consumo superior ao estimado para um certo período ou para atender a demanda normal em caso de entrega da nova aquisição". O estoque máximo é "a maior quantidade de material admissível em estoque, suficiente para o consumo em certo período, devendo-se considerar a área de armazenagem, disponibilidade financeira, imobilização de recursos etc" (SANTOS, 2012, p. 131).

Além dos estoques, também é de grande importância que as empresas projetem o seu fluxo de caixa. Ele "é uma ferramenta gerencial para ser usada em todas as atividades empresariais. O fluxo é o documento onde se organizam as informações da empresa. $\mathrm{O}$ fluxo de caixa ajuda a controlar o capital de giro, identifica os problemas que poderemos enfrentar e, ainda faz parte de um planejamento" (MARQUES, 1994, p. 62).

O cadastro de clientes também é essencial para as organizações, ele está diretamente ligado às tarefas de atendimento ao cliente. Com ele, a empresa tem a possibilidade de manter o registro de todos os atendimentos realizados ao cliente, produto e serviço disponibilizado a ele. Permite também a emissão de relatórios e dados acerca do mesmo (COSTA, 2002). 
Outro ponto a ser levado em consideração no local de trabalho é a ergonomia, ela tem o objetivo de trazer ao indivíduo maior conforto e satisfação através da análise e adequação do trabalho para que os mesmos não causem danos à saúde. Tendo em vista as condições, e tempo que o indivíduo realiza as tarefas, estas podem causar desconfortos e fadiga, podendo chegar a lesões. Para que isso não ocorra, é necessário analisar e adequar o trabalho ao ser humano (CORRÊA, BOLETTI, 2015).

Existem alguns benefícios decorrentes de uma ergonomia adequada no posto de trabalho, como conforto e segurança aos trabalhadores, menos acidentes de trabalho, aumento de produtividade e qualidade, redução de desperdícios, economias de energia, mão de obra, manutenção, redução de faltas de trabalho decorrentes de acidentes e doenças, redução de rotatividade, aumento de motivação, dentre outros (IIDA, 2000).

Segundo ele, além da ergonomia o uso das cores no ambiente de trabalho também são utilizados para o bem estar dos trabalhadores, ele influencia diretamente no estado emocional das pessoas, produtividade e qualidade do trabalho. Usar as cores adequadamente no local de trabalho e juntamente com uma iluminação adequada pode levar a resultados de até 30\% de economia no consumo de energia e aumentos de produtividade de 80 a $90 \%$.

No Quadro 1 são apresentadas as cores e suas associações.

Quadro 1 - Associações feitas com as corres

\begin{tabular}{|l|l|}
\hline Cor & Associações \\
\hline Vermelho & Saliente, agressiva, estimulante e dinâmica até o enervamento. \\
\hline Amarelo & $\begin{array}{l}\text { Evoca dominação, riqueza material e espiritual, calor, energia, } \\
\text { claridade, despeito, traição, solidão e desespero. }\end{array}$ \\
\hline Verde & Sugere imobilidade, alivia tensões e equilibra o sistema nervoso. \\
\hline Azul & $\begin{array}{l}\text { Calmo, repousante, indiferença, imprudência e passividade, } \\
\text { inteligência e raciocínio. }\end{array}$ \\
\hline Laranja & Evoca o fogo, sol, luz e calor, tem poder de dispersão. \\
\hline Branco & Pureza, paz, nascimento, morte, ausência, vácuo noturno. \\
\hline Preto & Deprimente, sombra, frio, caos, angústia, tristeza. \\
\hline
\end{tabular}

Fonte: Adaptado pela autora com base em Lida (2000, p. 268).

A gestão de processos abrange, além de todos tópicos citados acima, programas como os Cinco Sensos (5S), estes que ajudam as organizações na organização do posto de trabalho, otimização e melhoria dos resultados.

Este programa, criado no Japão, onde as palavras em japonês seiri, seiton, seisou, seiketsu e shitsuke, foram traduzidas para o português com os seguintes significados: utilização, ordenação, limpeza, saúde e autodisciplina. $\mathrm{O} 5 \mathrm{~S}$ quando praticado traz benefícios às empresas como redução de acidentes 
de trabalho, melhorias de qualidade e produtividade, aumento da autoestima, respeito com semelhante e com o ambiente, crescimento pessoal, aproximação das pessoas envolvidas, dentre outros (SILVA, 1994).

O Senso de Utilização tem o objetivo de identificar e classificar os recursos que não tem mais utilidade para o fim desejado, ou seja, eliminar tarefas que não são mais necessárias, excessos e desperdícios. Também diz respeito à utilização correta de equipamentos para que sua vida útil seja maior. Sua utilização traz a liberação de espaços antes ocupados, reaproveitamento de recursos, diminuição de custos, realocação de pessoal e outros, acrescenta ele.

Já o Senso de Ordenação, segundo ele, diz respeito à disposição dos objetos, layout, assim como uma boa comunicação visual, para que facilite o acesso de pessoas e o fácil acesso as coisas. Ele traz economia de tempo, menor movimentação desnecessária e outros.

O Senso de Limpeza para ele é a limpeza do posto de trabalho realizado pela mesma pessoa que utiliza e que ao mesmo tempo é responsável e consciente pelo cuidado para não sujar, com o objetivo de um posto de trabalho agradável. Os benefícios decorrentes deste Senso são: bem estar pessoal, manutenção de equipamentos, prevenções de acidentes e boa impressão as pessoas que visualizam o local.

O Senso de Saúde objetiva a preocupação que o indivíduo deve ter com sua própria saúde em nível físico, mental e emocional. Proporciona um local de trabalho agradável, diminuição de acidentes, prevenção de doenças, equipe saudável e disposta, acrescenta ele.

O Senso de Autodisciplina para ele ocorre quando o indivíduo segue os padrões técnicos, éticos e morais sem de controle de outras pessoas, ela executa o combinado quando a decisão é tomada. Com isso é possível prever os resultados, ter maior autocontrole, melhoria contínua pessoal e organizacional.

\section{MÉTODO DE PESQUISA}

Esta etapa do artigo objetiva apresentar os procedimentos metodológicos utilizados neste estudo, podendo ser classificados quanto seus objetivos, natureza de abordagem e procedimentos técnicos.

Este estudo é classificado como um projeto de pesquisa aplicada. Para Vergara (2010, p. 43), “a pesquisa aplicada é fundamentalmente motivada pela necessidade de resolver problemas concretos, mais imediatos, ou não. Tem, portanto, finalidade prática". Deste modo, desenvolveu-se um estudo de caso, aplicado somente a Oficina Mecânica. "Estudo de caso é o circunscrito a uma ou poucas unidades, entendidas essas como pessoa, família, produto, empresa, órgão público, comunidade ou mesmo país. Utiliza métodos diferenciados de coleta de dados" (VERGARA, 2010, p. 44). 
Quanto à abordagem do problema, esta pesquisa é classificada como qualitativa. "A pesquisa qualitativa proporciona maior visão e compreensão do problema. Ela o explora com poucas ideias preconcebidas sobre o resultado dessa investigação". (MALHOTRA, ROCHA, LAUDISIO, 2005, p. 113).

Ao realizar este estudo, dados primários foram utilizados, os quais foram coletados da empresa analisada através de conversas informais e análise do ambiente; os dados secundários foram retirados de livros e publicações em meio eletrônico. "Quando os dados são coletados para solucionar um problema específico de pesquisa de marketing, nos referimos a eles como dados primários" (MALHOTRA et al., 2005, p. 71). "Dados secundários representam quaisquer dados que já foram coletados para outros propósitos além do problema em questão" (MALHOTRA, ROCHA, LAUDISIO, 2005, p. 72).

\section{APRESENTAÇÃO E ANÁLISE DO PROCESSO ATUAL}

Os processos atuas da empresa são apresentadas através de um desenho realizado através de um software, e a seguir todo processo descrito apresentando seus atuais problemas. Vale destacar que este trabalho propõe o estudo dos processos de atendimento aos fornecedores para compra de mercadorias, entregadores para entrega de mercadoria e atendimento aos clientes para serviços de guincho específico para fretes de veículos.

\subsection{Fluxograma do processo atual da empresa}

O fluxograma a seguir Figura 3 e Figura 4, representam o atual processo de atendimento aos clientes, fornecedores e entregadores realizados pela empresa em questão. Ele foi desenvolvido com o software Bizagi Process Modeler. 
Figura 3 - Fluxograma do processo atual

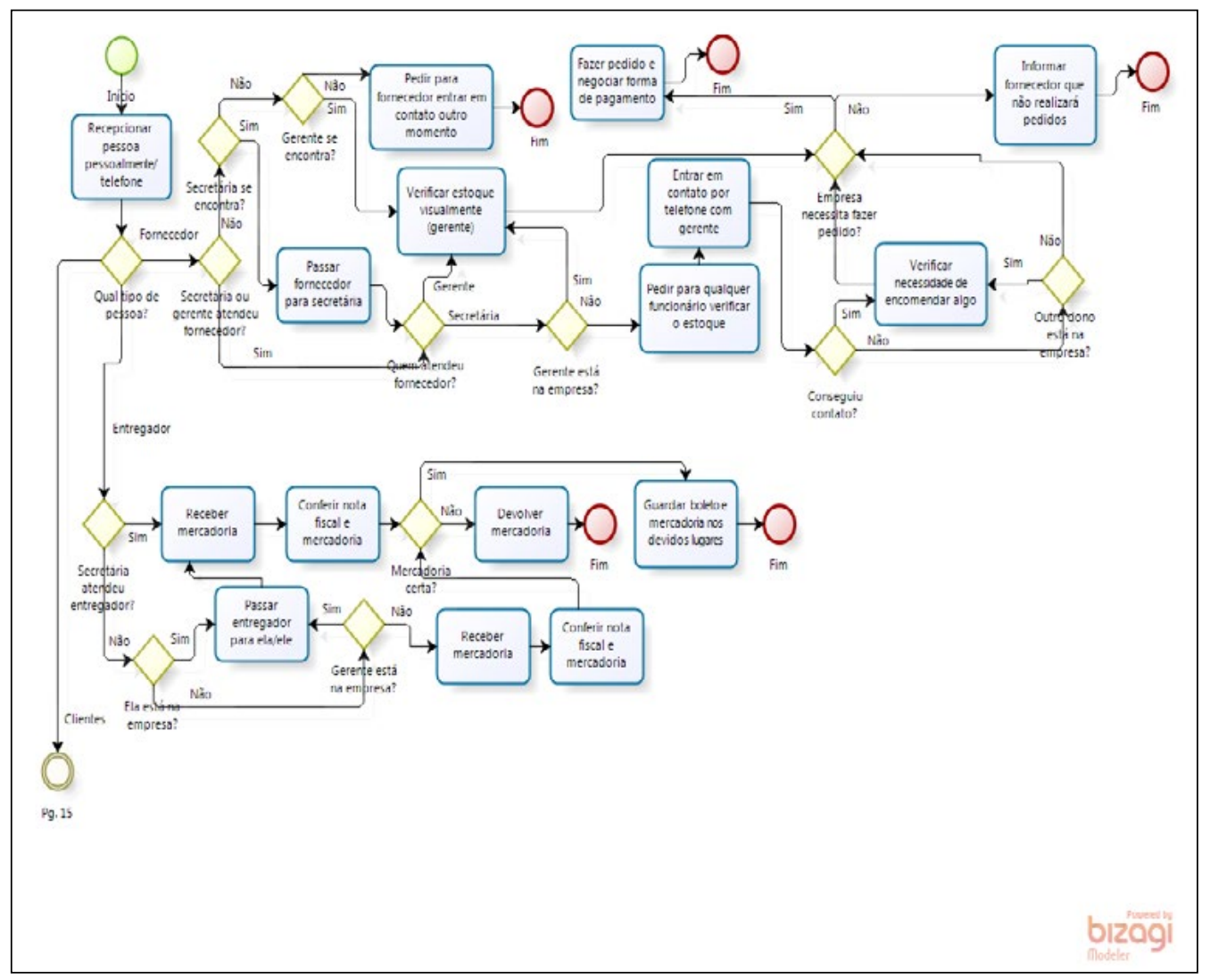

Fonte: Elaborado pela autora. 
Figura 4 - Continuação do Fluxograma do processo atual

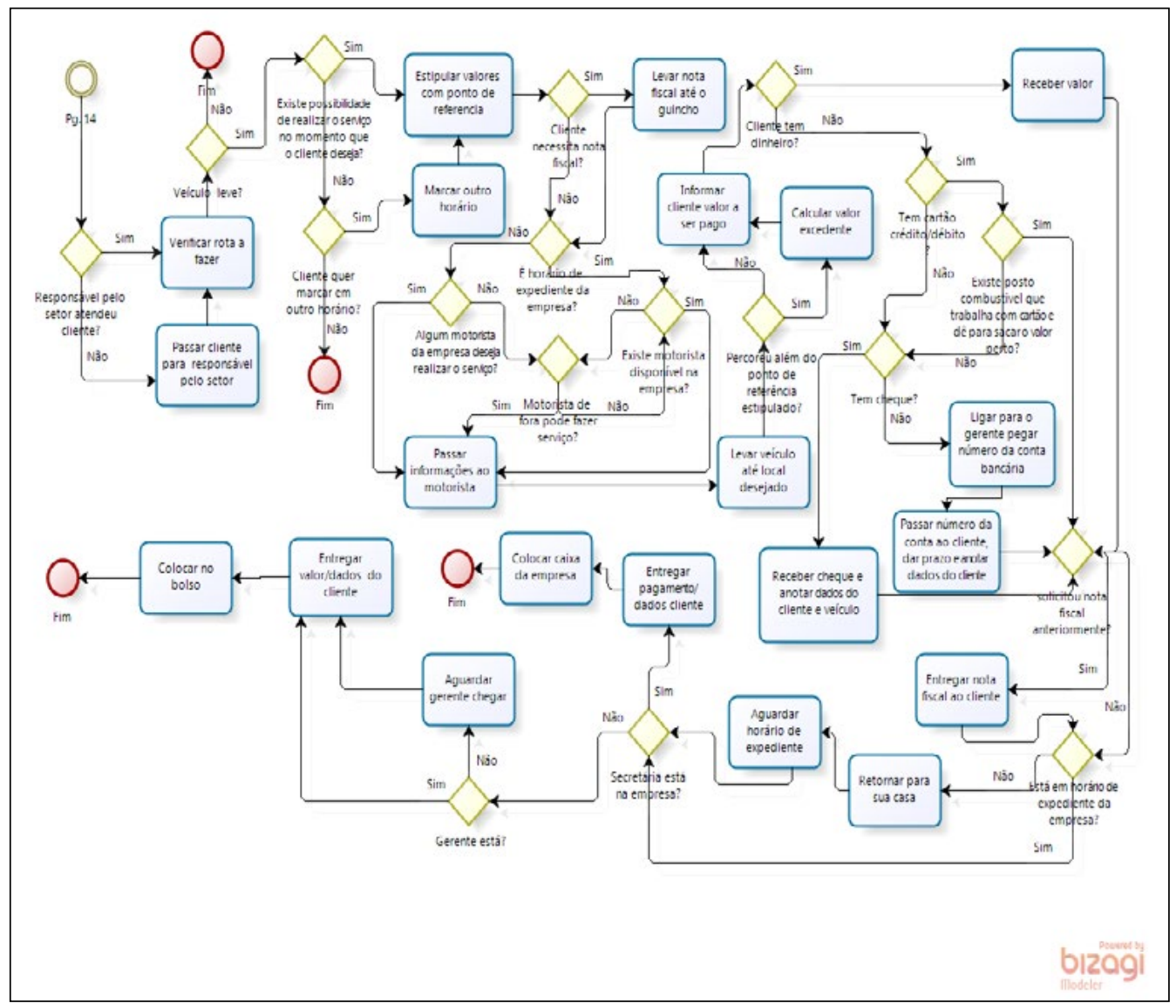

Fonte: Elaborado pela autora.

\subsection{Descrição do processo atual}

A pessoa ao procurar a empresa para a prestação de serviços venda ou entrega de mercadorias, este pessoalmente, ou através dos telefones tanto da empresa quanto dos colaboradores, são recepcionados por qualquer pessoa que trabalhe na empresa. O fato qualquer pessoa atender os clientes, fornecedores e entregadores resulta em paradas e atrasos na prestação de serviços.

Se esta pessoa for um fornecedor, ele é atendido preferencialmente pela secretária ou pelo dono e gerente da empresa, caso eles não estiverem na empresa, é solicitado que ele entre em contato em outro momento. Este fato faz com que muitas vezes a empresa não compre o necessário para prestar manutenção nos veículos, pois o fornecedor acaba não entrando em contato novamente com a empresa. 
O gerente se estiver na empresa visualiza os estoques, caso ele não estiver outro funcionário é encarregado de verificar o que necessita ser encomendado, então a secretária tenta entrar em contato por telefone com o gerente, caso não consiga, se o outro dono da empresa estiver na mesma, é perguntado a ele se necessita fazer mais alguma encomenda, tudo é passado ao fornecedor e as formas de pagamento negociadas. $\mathrm{O}$ fato de visualizar os estoques para fazer encomendas ocasiona certa dificuldade em verificar suas necessidades, pois a empresa acaba comprando itens que já existem em excesso, deixando de comprar alguns necessários, pois acreditam que os mesmos encontram-se disponíveis.

Outro ponto a ser destacado é a dificuldade que a secretária enfrenta quando tem que entrar em contato com os colaboradores para que os pedidos sejam efetuados, ocasionando em demoras nos atendimentos, gastos com telefonemas além do gerente ou funcionários muitas vezes ter que se deslocar diariamente para outra cidade em busca de peças e acessórios, dificultando o dia a dia da empresa, pois tudo que necessita de alguma decisão, há necessidade de entrar em contato com o gerente, Outro ponto a destacar é que a mesma conta com vários estoques espalhados pela empresa inclusive um deles junto com peças da prefeitura da cidade, dificultando a visualização e localização de peças para manutenção de veículos, ou seja, há necessidade de se deslocar pelos estoques para encontrar o que necessitam, pois há muitas coisas inúteis ocupando espaço e favorecendo a falta de limpeza e desorganização do local.

Quando a mercadoria é entregue a empresa, ela é recebida preferencialmente pela secretária ou gerente, caso nenhum estiver, qualquer colaborador confere a nota fiscal e a mercadoria, guarda o boleto de pagamento e mercadoria. Devido a falta de registros dos itens que a empresa possui em estoque, o gerente não sabe se as peças que foram trocadas nos veículos estão na garantia ou não, então sempre que o cliente reclama a empresa por não ter onde consultar os dados referente ao concerto do veículo da razão ao cliente e acaba perdendo valores.

Quando se trata de um cliente, procura-se saber qual tipo de serviço ele deseja. Se este cliente não for atendido pelo gerente da empresa, o mesmo é procurado para solucionar o problema, em casos onde ele não se encontra um mecânico ou motorista que possa dar assistência a tal serviço é procurado e o cliente então passado para ele. $O$ fato de chamar o gerente toda vez que necessita de uma decisão para realizar serviços, acaba atrapalhando a rotina do mesmo pois ele acaba deixando de lado o que estava fazendo para resolver o problema atual, e este problema ocorre em todas as decisões que os funcionários precisam tomar pois tudo está muito centralizado a ele.

Se o serviço solicitado pelo cliente é de frete de veículos, informações sobre a rota que o cliente deseja são levantadas, assim como a disponibilidade do mesmo para realizar o serviço. Neste momento encontra-se dificuldades, pois não há registros para saber se o mesmo encontra-se disponível no horário 
solicitado, então é perguntado aos colaboradores se o mesmo encontrase disponível, ocasionando na demora no atendimento. Os valores são estipulados no momento que o serviço é solicitado, estes valores são colocados através de pontos de referências e se o veículo for além deste ponto estipulado, é adicionado um valor para cada quilometro rodado a partir do ponto de referência. Também é perguntado neste momento ao cliente se ele necessita de nota fiscal, e se este necessitar, o talão de notas é levado junto para que após a nota fiscal seja entregue.

O dono verifica a disponibilidade dos motoristas, se estes estão ocupados, uma terceira pessoa é chamada, esta que não trabalha na empresa, se o dono não estiver na empresa, um motorista é convocado para prestar serviço. $\mathrm{O}$ guincho leva o veículo até o destino, calcula o valor a ser cobrado se cliente tem o valor em dinheiro, recebe valor, se tiver cartão de crédito ou débito e existir um posto de combustível perto do local, é negociado com o dono do posto para o valor ser sacado, caso não exista e ele tiver cheque, recebe valor em cheque, anota dados do cliente e do veiculo, caso não tenha nem cheques, motorista liga para gerente passar número da conta bancária e então passar para cliente, combinando prazo para que o valor seja depositado e anotando dados do cliente e do veículo. Devido a empresa não ter outros meios de pagamento, ocorre que o cliente as vezes só dispõe de cartões então não é garantido o recebimento dos valores caso ele não deposite o valor combinado ou o cheque seja sem fundo. Também não tem como cobrar o valor pois não há registros para comprovar que o serviço foi realizado.

O motorista retorna a oficina e se ele recebeu o valor, cheque ou dados do cliente, ele entrega para a secretária no administrativo e ela coloca no caixa da empresa, e se esta não estiver, entrega para o dono e ele coloca no bolso. Devido a falta de registros, a empresa não sabe se o serviço é viável ou não pois o valor vai direto para o bolso do dono sem registros de caixa.

Quando o serviço é realizado fora do horário de expediente da empresa, um funcionário é chamado para ver se este pode realizar o serviço, se não procura outro de fora da empresa. Ao retornar, ele volta para sua casa e retorna com o veículo e o valor referente ao serviço no seu horário de expediente, devolvendo a secretária ou ao dono o valor ou dados do possível pagamento conforme descrito anteriormente. Neste caso, podem haver percas por parte da empresa, pois não contam com registros de dados referente aos serviços realizados pelo veículo, assim como registros de caixa.

\subsection{Sobre as instalações}

Sua estrutura é de material o chão é de cimento bruto o que dificulta a limpeza do local, pois quando varrem a poeira levanta e suja todos os móveis da empresa. Geralmente a secretária é a responsável pela limpeza do local, assim como serviços de banco, recepcionista e afazeres familiares do dono da 
oficina. Devido ao acúmulo de funções, ocorre de esta não conseguir realizar todas as tarefas, ocasionando na demora na prestação de serviços da empresa.

As instalações elétricas da empresa encontram-se precárias, assim como o sistema de alarme sem pontos em locais apropriados. Existe apenas um banheiro que é utilizado tanto para clientes quanto para funcionários, homens e mulheres, porém este não pode ser utilizado para cadeirante, devido ao espaço que ele ocupa ser muito pequeno. Coisas inúteis, que servem para ferro velho, acessórios usados, mas que podem ser reutilizados e coisas familiares são armazenados em todos os locais da empresa favorecendo a desorganização e a falta de limpeza do ambiente.

Parte dos estoques ficam expostos em prateleiras com livre acesso, assim como ferramentas de alto valor ficam dispostas em painéis nas paredes. Este local às vezes no final da tarde acaba ficando sozinho e aberto, pois os funcionários terminam seu expediente e ficam poucas pessoas na empresa.

Para os clientes, a empresa oferece uma sala de espera com móveis e utensílios que não estão em bom estado, que também é utilizada por funcionários quando não há clientes. Disponibilizam água e café, porém não há copos descartáveis, apenas xícaras, pois os mesmos eram utilizados pelos funcionários em grande quantidade. O local é aberto, sem divisões o que dificulta que o cliente assista e escute televisão por causa do barulho gerado na prestação de serviços. $O$ administrativo da empresa também enfrenta problemas com excesso de barulho dificultando o atendimento ao cliente.

Nos setores de manutenção há placas de identificação de proibido fumar, porém estas muitas vezes não são respeitadas pelos funcionários. A fumaça que os carros largam deixam o local com cheiro. Geralmente as ferramentas não são guardadas no final do expediente, algumas ficam espalhadas pelo chão e geralmente são ajuntadas pelo dono da empresa quando acha necessário.

Para que estes problemas sejam solucionados, um novo processo de atendimento a clientes fornecedores e entregadores é proposto.

\section{MODELO PROPOSTO}

Para a melhoria dos processos estudados, foi utilizado o fluxograma de processos para desenhar o processo atual e também para redesenhar os processos com as melhorias propostas à empresa conforme a Figura 5 e Figura 6. 
Figura 5 - Fluxograma do processo proposto

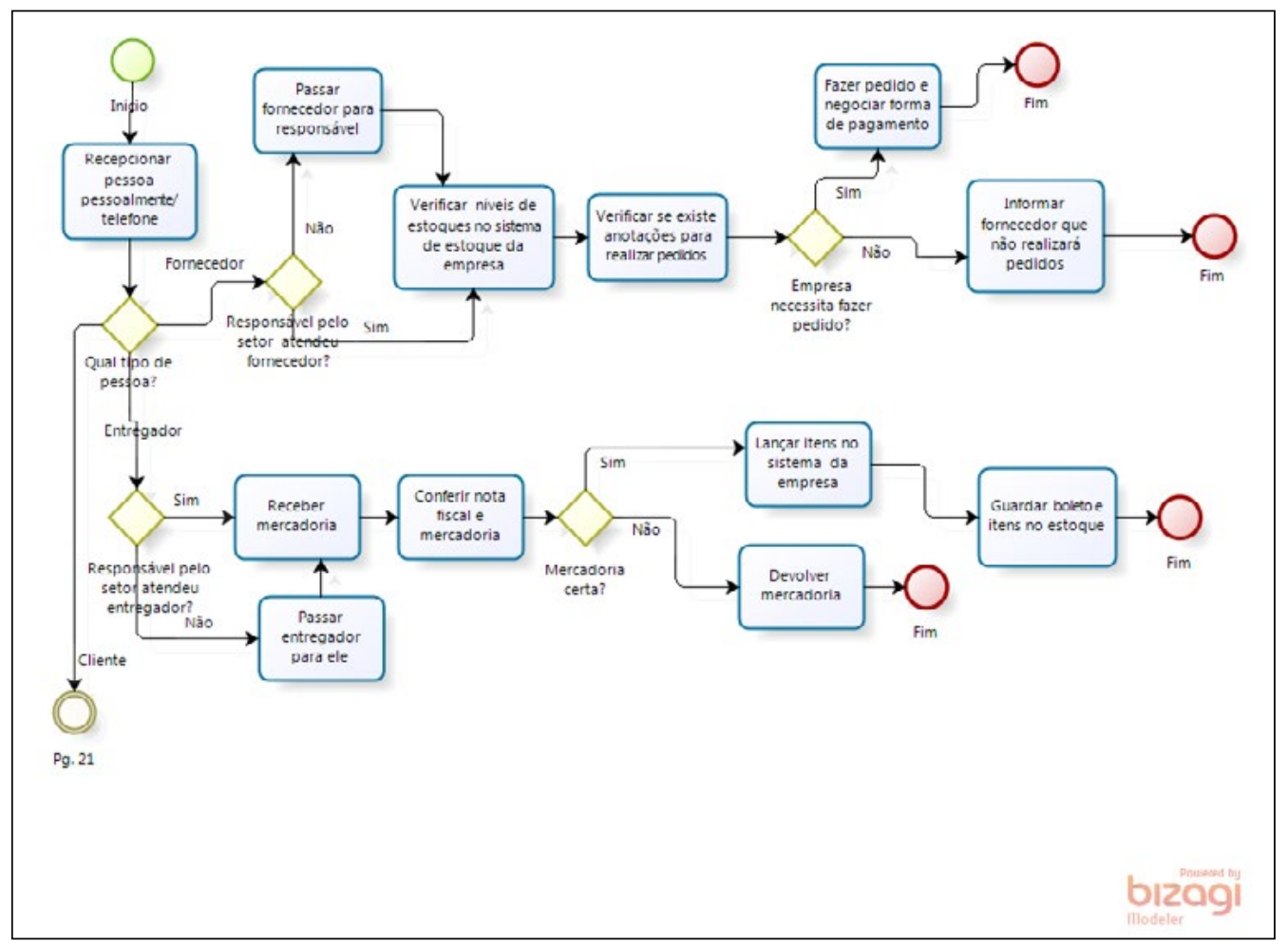

Fonte: Elaborado pela autora. 
Figura 6 - Continuação do Fluxograma do processo proposto

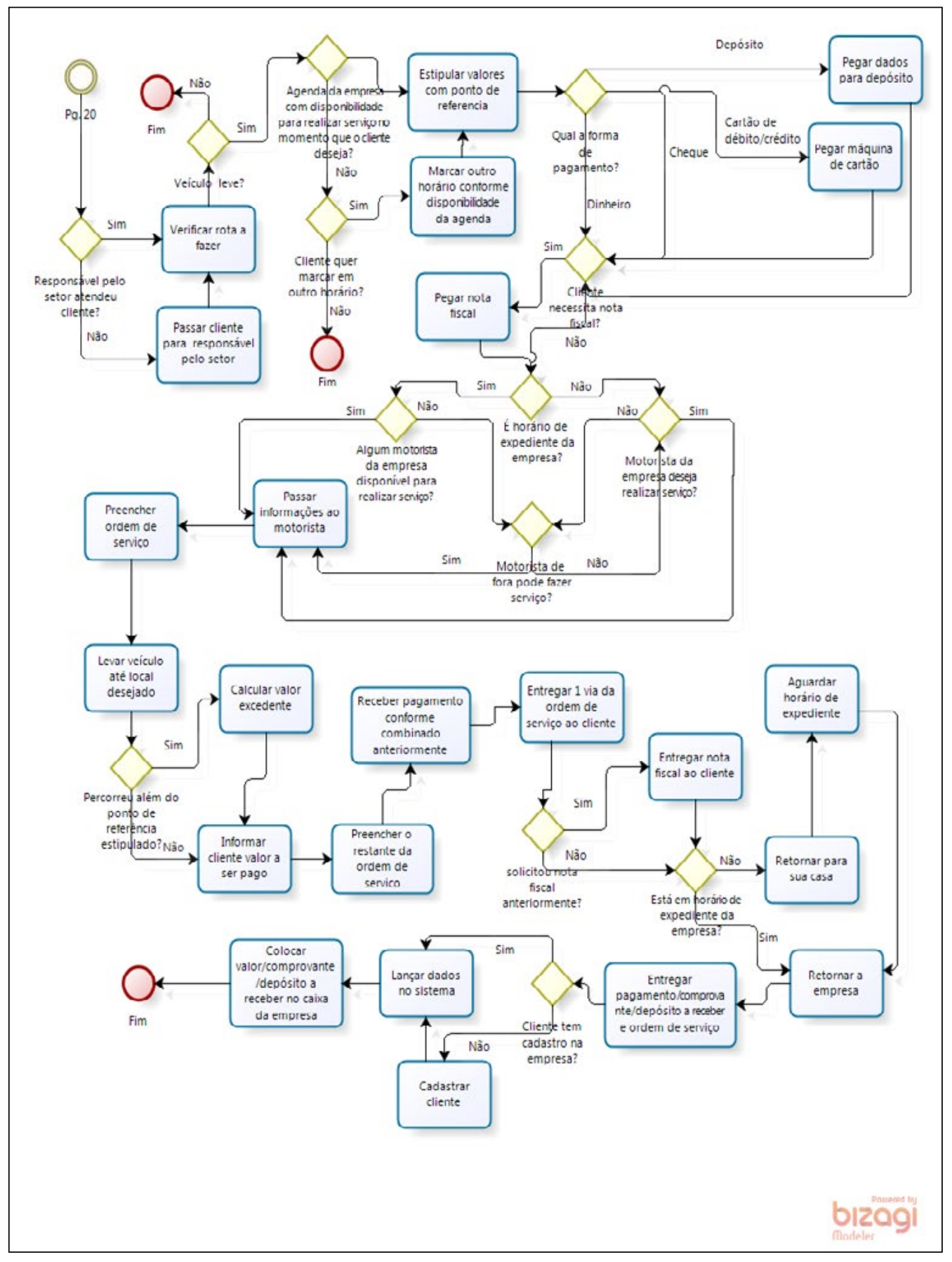

Fonte: Elaborado pela autora. 


\subsection{Descrição do processo proposto}

A pessoa ao procurar a empresa, esta pessoalmente ou por telefone, deve ser atendida por alguém que trabalhe na empresa, preferencialmente pelo responsável pelo setor administrativo e de atendimento. Em relação aos problemas de atendimento, sugere-se o treinamento da secretária, do gerente e de mais um funcionário para tarefas do setor administrativo e de atendimento as pessoas, para que quando um não esteja do local, outro encarregado pelo setor assuma estas responsabilidades. Deve-se também centralizar tarefas de atendimento as pessoas e tarefas administrativas apenas para pessoas que trabalham neste setor.

Quando se trata de um fornecedor, o responsável pelo setor confere os níveis de estoques da empresa no sistema de estoque da empresa, assim como as anotações realizadas pelos mecânicos para compras em especial, então se existe algo a ser encomendado os pedidos necessários são realizados e as formas de pagamentos negociadas. Em relação aos problemas deste setor, pode se sugerir que a empresa treine o pessoal para este fim como dito anteriormente, compre um computador propício para este setor, instale um software para gerenciar a empresa, o qual abrange módulos como o de controle de estoque. Deve-se também calcular níveis mínimos e máximos de estoque para que quando eles atingirem os níveis mínimos a empresa saiba o momento de fazer as encomendas. Também ela deve disponibilizar um caderno para que as anotações dos mecânicos referente a peças especiais sejam realizadas para que quando encomendas sejam realizadas estas anotações também sejam conferidas e encomendadas quando necessário.

O fato de existir um controle de estoques, caderno de anotações e pessoas capacitadas evita que dificuldades sejam enfrentadas assim como demoras nos atendimentos e gastos desnecessários. Esta centralização de atividades evita que o gerente tenha que ser consultado em todas as tarefas. Para que isso seja possível, a empresa deve unificar os estoques, colocando-os em um único local para que seja mais fácil a visualização das peças no momento de retirá-las de estoque, organizando-as para que cada item fique em local definido, mantendo a organização e a limpeza do local, retirando tudo que não seja estoque da empresa.

Outros itens como ferro velho devem ser colocados em um local apropriado e também coisas da família devem ser guardados em outro local, mas para que isso seja possível há necessidade de um redesenho do layout da empresa realizado por um profissional da área e também deve-se levar em conta o Senso de Utilização com o objetivo de liberar espaços que antes eram ocupados sem necessidade e o Senso de Ordenação com o objetivo de deixar o local com uma boa comunicação visual, facilitando o acesso as coisas. Também podemos levar em conta neste momento, o uso das corres para deixar o ambiente mais harmonioso e proporcionar um maior bem estar a todos que trabalham na empresa. 
Se este for um entregador, o responsável deve receber a mercadoria, conferi-las, conferir a nota fiscal se estiver certa lançar os itens no sistema e guarda-los no estoque. Caso não esteja certo, devolvê-las a empresa. Em relação aos problemas neste processo, pode-se sugerir a instalação de um software este dito anteriormente, que abranja além de um módulo de cadastro de estoques, um módulo de cadastro de clientes, este com todos os dados necessários referente aos clientes e aos serviços realizados, com isso, a empresa saberá exatamente o momento que as peças foram trocadas em determinado veículo evitando a perca de valores referente a garantias de peças.

Se este for um cliente para serviços de guincho, um responsável pelo setor administrativo atende o cliente, verifica se o veículo é leve, caso não seja, a empresa não realiza serviços para veículos pesados, então, verifica-se a agenda da empresa conforme as disponibilidades da empresa, se o serviço não pode ser realizado no momento que o cliente quer, outro horário é marcado caso ele deseje.

Se o cliente preferir realizar o pagamento com cartão, a máquina de cartão da empresa deve ser levada junto, se em depósito, dados da conta da empresa devem ser levados junto. Se o cliente desejar nota fiscal, a mesma deve ser levada junto. Se for horário de expediente da empresa e existir um motorista disponível este é encarregado de realizar o serviço, caso este não possa, outro motorista de fora é contatado, caso este também não possa o motorista da empresa é destinado, então as informações são passadas ao motorista, parte da ordem de serviço preenchida com os dados necessários, veículo é levado ao local desejado, valor a cobrar é calculado, o restante da ordem de serviço é preenchido, o pagamento é recebido conforme o combinado, uma via desta ordem é entregue ao cliente, se ele solicitou nota fiscal esta também é entregue a ele.

Se for horário de expediente da empresa o motorista retorna a empresa e entrega ao responsável do setor a ordem de serviço e o pagamento ou comprovante conforme o combinado anteriormente com o cliente, então a secretária verifica se o cliente tem cadastro na empresa se tiver os dados são lançados no sistema da empresa caso não tenha, um cadastro é criado e então os dados lançados, o valor ou comprovantes ou depósito a receber no caixa da empresa.

Em relação aos problemas deste processo, a empresa deve disponibilizar uma agenda de atendimentos para que seja possível marcar horários de atendimentos em que o veículo esteja disponível, assim como a centralização desta atividade para o responsável do setor administrativo e de atendimento evitando que o gerente seja chamado toda vez que tenha que marcar algum horário. Verifica-se a forma de pagamento, se em dinheiro, cheque, cartão ou depósito bancário. Neste caso, a empresa deve adquirir uma máquina de cartão de débito e crédito para facilitar a forma de pagamento dos clientes à empresa, assim como o número da conta bancária da empresa para que seja levada junto 
com o motorista com objetivo de facilitar e diminuir o tempo do processo de atendimento.

Sugere-se a implantação de uma ordem de serviço disposta em duas vias para que uma no final do atendimento seja entregue ao cliente. Nesta deve conter dados a cerca do momento que o serviço é prestado, cliente, rota, quilometragem, dentre outros que possam ser importantes para que a empresa cadastre seus clientes, faça cobranças e análises a cerca da viabilidade do serviço prestado.

Como dito anteriormente, a empresa necessita de um software com módulo de cadastro de clientes para que o dia a dia da empresa seja registrado com intuito de facilitar possíveis consultas e emissão de relatórios para possíveis análises. Vale destacar, que para atividades do dia a dia da empresa, também há necessidade de um fluxo de caixa para que as contas da empresa sejam controladas conforme a necessidade do setor, facilitando possíveis investimentos.

\subsection{Sobre as instalações}

Sobre as instalações vale ressaltar que a empresa necessita realizar alguns reparos para melhoria do ambiente de trabalho e para que as tarefas diárias fiquem mais fáceis de serem realizadas, evitando alguns riscos. Ela deve realizar a manutenção preventiva do local. Sugere-se que o layout da empresa seja redesenhado por uma pessoa capacitada a fim de tornar as tarefas mais fáceis e harmoniosas. Para a sala do administrativo e de espera, sugere-se que seja colocado algum tipo de piso para que facilite a limpeza do local, também que seja considerado a possibilidade de colocar um isolamento acústico para que a poeira e o barulho não atrapalhem o atendimento aos clientes.

A secretária da empresa deve realizar serviços apenas para a empresa em seu horário de expediente diminuindo atrasos nos atendimentos. Instalações elétricas devem ser revisadas por um profissional capacitado e então realizado os devidos reparos sugeridos por ele. Pontos de alarme também devem ser colocados em locais necessários para a segurança da empresa, assim como devidos reparos no sistema existente. $\mathrm{O}$ banheiro deve seguir as normas regulamentadoras de trabalho.

Devem ser destinados lugares próprios para acúmulo de coisas a serem descartadas, estes unificados em apenas um local e não em toda empresa, assim como a unificação dos estoques da empresa sem livre acesso a fim de manter a organização e limpeza do local e evitar possíveis problemas. Câmeras de segurança devem ser instaladas no local a fim de monitorar o local no final do dia quando quase todos já saiam da empresa.

Alguns móveis devem ser trocados, pois já não estão em bom estado, com intuito de manter o local agradável. Para evitar que os funcionários utilizem copos em excesso, a empresa deve dispor de um local apropriado para 
funcionários para que eles possam desfrutar do local evitando desperdícios. Conforme dito anteriormente, seria de grande importância que o redesenho do layout seja realizado, modificando o necessário para maior segurança e comodidade, destacando que locais como salas de espera e setor administrativo sejam locais com isolamento acústico a fim de proporcionar maior comodidade.

Regras devem ser colocadas e cobradas dos funcionários para que mantenham o local limpo e organizado utilizando o senso de limpeza, o qual cada um dentro da empresa faz a sua parte mantendo seu posto de trabalho limpo, assim como o senso de saúde o qual a limpeza do local ajuda as pessoas se manterem saudáveis. Vale destacar que o senso de autodisciplina vem a seguir quando as pessoas cumprem com o que foi combinado sem a necessidade de cobranças por parte da gerência.

Vale destacar também que exaustores devem ser colocados para que a fumaça que os carros geram sejam sugados para fora. Ferramentas devem ser guardadas em seus devidos lugares no final de cada serviço realizado com o objetivo de cada um que necessite delas encontre-as com facilidade.

Para que haja maior compreensão e praticidade no momento dos gestores solucionarem os problemas existentes na empresa, um resumo referente aos problemas e devidas soluções foi elaborado e organizado no Quadro 2.

Quadro 2 - Quadro resumo

\begin{tabular}{|c|c|c|}
\hline & Problema & Solução \\
\hline 1. & $\begin{array}{l}\text { Qualquer pessoa atende clientes, } \\
\text { fornecedores e entregadores. }\end{array}$ & $\begin{array}{l}\text { Treinar secretária, gerente e um funcionário } \\
\text { para funções do setor administrativo e de } \\
\text { atendimento as pessoas para suprir a demanda } \\
\text { do mesmo quando alguém se ausentar, } \\
\text { centralizando as atividades de atendimento a } \\
\text { este setor. }\end{array}$ \\
\hline 2. & $\begin{array}{l}\text { Empresa não compra } \\
\text { mercadorias se o gerente ou a } \\
\text { secretária não estão na empresa. }\end{array}$ & $\begin{array}{l}\text { Treinar pessoal para este fim como dito } \\
\text { anteriormente, comprar um computador, } \\
\text { instalar um software para gerenciar a empresa } \\
\text { com módulo para controle de estoques, o qual } \\
\text { indique níveis de estoque para que o mesmo } \\
\text { seja reposto quando necessário. }\end{array}$ \\
\hline 3. & $\begin{array}{l}\text { Dificuldades } \text { de visualizar } \\
\text { os estoques visivelmente e } \\
\text { verificar o que necessita ser } \\
\text { encomendado. }\end{array}$ & $\begin{array}{l}\text { Treinar pessoal para este fim e comprar um } \\
\text { computador e software para gerenciar a } \\
\text { empresa como dito anteriormente, assim como } \\
\text { disponibilizar um caderno para anotações } \\
\text { aos mecânicos referentes a peças a serem } \\
\text { encomendas que não existam em estoque, } \\
\text { além de calcular níveis de estoques mínimos e } \\
\text { máximos. }\end{array}$ \\
\hline
\end{tabular}




\begin{tabular}{|c|c|c|}
\hline & Problema & Solução \\
\hline 4. & $\begin{array}{l}\text { Dificuldade de entrar em } \\
\text { contato com o gerente para fazer } \\
\text { encomenda de mercadorias, } \\
\text { assim como de falar com os } \\
\text { funcionários para ver se eles } \\
\text { necessitam de algo. }\end{array}$ & $\begin{array}{l}\text { Disponibilizar computador com software, } \\
\text { agenda e pessoas capacitadas como dito } \\
\text { anteriormente. }\end{array}$ \\
\hline 5. & $\begin{array}{l}\text { Demoras no atendimento e } \\
\text { gastos com telefonemas para } \\
\text { entrar em contato com gerente e } \\
\text { funcionários. }\end{array}$ & $\begin{array}{l}\text { Centralizar tarefas para administrativo } \\
\text { e atendimento de pessoas assim como } \\
\text { disponibilizar caderno, computador com } \\
\text { software e pessoas capacitadas como citado } \\
\text { anteriormente. }\end{array}$ \\
\hline 6. & $\begin{array}{l}\text { Necessidade de alguém da } \\
\text { empresa se deslocar para outra } \\
\text { cidade em busca de peças e } \\
\text { acessórios. }\end{array}$ & $\begin{array}{l}\text { Calcular níveis mínimos e máximos de estoque } \\
\text { para que as peças sejam compradas e não faltem } \\
\text { quando necessário. }\end{array}$ \\
\hline 7. & $\begin{array}{l}\text { Dificuldade de entrar em } \\
\text { contato com o gerente quando } \\
\text { este não está na empresa para } \\
\text { tomar decisões. }\end{array}$ & $\begin{array}{l}\text { Treinar pessoal e centralizar as funções como } \\
\text { dito anteriormente para que exista sempre } \\
\text { alguém encarregado do setor quando alguém se } \\
\text { ausentar, podendo assim este tomar as decisões } \\
\text { necessárias. }\end{array}$ \\
\hline 8. & $\begin{array}{l}\text { Vários estoques espalhados } \\
\text { pela empresa dificultando } \\
\text { a visualização de peças e } \\
\text { acessórios. }\end{array}$ & $\begin{array}{l}\text { Unificar os estoque em um único local, e } \\
\text { organizar os itens em locais definidos. }\end{array}$ \\
\hline 9. & $\begin{array}{l}\text { Coisas inúteis espalhadas pela } \\
\text { empresa, ocupando espaço e } \\
\text { favorecendo a falta de limpeza e } \\
\text { desorganização do local. }\end{array}$ & $\begin{array}{l}\text { Utilizar o senso de ordenação e utilização e } \\
\text { redesenhar o layout da empresa tendo em vista } \\
\text { o uso das corres para uma maior harmonia no } \\
\text { local. }\end{array}$ \\
\hline 10. & $\begin{array}{l}\text { Dificuldade em saber se peças } \\
\text { trocadas em veículos estão na } \\
\text { garantia ou não. }\end{array}$ & $\begin{array}{l}\text { Implantar software d } \\
\text { módulo de cadastro } \\
\text { cada atendimento sej }\end{array}$ \\
\hline 11. & $\begin{array}{l}\text { Empresa perde a razão diante } \\
\text { do cliente, pois não tem como } \\
\text { verificar dados referentes à troca } \\
\text { de peças e concerto de veículos. }\end{array}$ & $\begin{array}{l}\text { Implantar software de gerencia da empresa } \\
\text { com módulo de cadastro de clientes e serviços } \\
\text { onde cada atendimento seja cadastrado para } \\
\text { que posteriormente possa ser analisado quando } \\
\text { necessário. }\end{array}$ \\
\hline 12. & $\begin{array}{l}\text { Dificuldades em saber se o } \\
\text { guincho encontra-se disponível. }\end{array}$ & $\begin{array}{l}\text { Disponibilizar uma agenda de atendimentos } \\
\text { para marcar horários. }\end{array}$ \\
\hline 13. & $\begin{array}{l}\text { Necessidade de chamar o } \\
\text { gerente ou algum funcionário } \\
\text { para tomar decisões a cerca de } \\
\text { realização de serviços. }\end{array}$ & $\begin{array}{l}\text { lizar tarefa ao responsável pelo setor } \\
\text { istrativo e de atendimento as pessoas. }\end{array}$ \\
\hline 14. & $\begin{array}{l}\text { Demora no atendimento, pois } \\
\text { necessita procurar funcionários. }\end{array}$ & $\begin{array}{l}\text { Disponibilizar uma agenda de atendimentos } \\
\text { e centralizar tarefa ao responsável pelo setor } \\
\text { como dito anteriormente. }\end{array}$ \\
\hline
\end{tabular}




\begin{tabular}{|c|c|c|}
\hline & \begin{tabular}{|l|} 
Problema \\
\end{tabular} & Solução \\
\hline 15. & $\begin{array}{|lcr|}\text { Dificuldades } & \text { em } & \text { receber } \\
\text { pagamentos, } & \text { pois } & \text { clientes } \\
\text { geralmente } & \text { trabalham } & \text { com } \\
\text { cartões de débito e crédito. }\end{array}$ & $\begin{array}{l}\text { Implantar máquinas de cartões de débito e } \\
\text { crédito e levar número da conta da empresa em } \\
\text { caso de depósitos. }\end{array}$ \\
\hline 16. & $\begin{array}{l}\text { Inadimplência de clientes que } \\
\text { fazem pagamentos em cheques } \\
\text { e dos que preferem realizar } \\
\text { depósitos e não realizam. }\end{array}$ & $\begin{array}{l}\text { Disponibilizar ordem de serviço disposta em } \\
\text { duas vias com todas informações necessárias do } \\
\text { cliente, veículo e rota percorrida, para que possa } \\
\text { cobra o cliente caso este seja um inadimplente. }\end{array}$ \\
\hline 17. & $\begin{array}{l}\text { Não conhecem a viabilidade do } \\
\text { negócio. }\end{array}$ & $\begin{array}{l}\text { Implantar fluxo de caixa através de um software } \\
\text { com módulo para este fim com objetivo de } \\
\text { gerenciar a empresa. }\end{array}$ \\
\hline 18. & $\begin{array}{l}\text { Percas decorrentes de falta de } \\
\text { registros. }\end{array}$ & $\begin{array}{l}\text { Disponibilizar ordem de serviço em duas } \\
\text { vias onde uma fica com o cliente e outra } \\
\text { com a empresa dispondo todas informações } \\
\text { necessárias a respeito do cliente e serviços } \\
\text { conforme dito anteriormente. }\end{array}$ \\
\hline 19. & $\begin{array}{l}\text { Dificuldade de manter o local } \\
\text { limpo. }\end{array}$ & $\begin{array}{l}\text { Utilizar senso de limpeza e de saúde, onde cada } \\
\text { um cuida para manter seu posto de trabalho } \\
\text { limpo, colaborando também para sua saúde. }\end{array}$ \\
\hline 20. & $\begin{array}{l}\text { Acúmulo de funções para a } \\
\text { secretária ocasiona demora na } \\
\text { prestação de serviços. }\end{array}$ & $\begin{array}{l}\text { Deixar de fazer afazeres pessoais, fazendo } \\
\text { apenas afazeres da empresa, o que compete } \\
\text { ao cargo como atendimento às pessoas e } \\
\text { administrativo. }\end{array}$ \\
\hline 21. & Instalações elétricas precárias. & $\begin{array}{l}\text { Chamar um especialista da área para verificar } \\
\text { as instalações dando a manutenção necessária } \\
\text { para que o local não ofereça riscos. }\end{array}$ \\
\hline 22. & $\begin{array}{l}\text { Sistema de alarme precário sem } \\
\text { pontos em locais específicos. }\end{array}$ & $\begin{array}{l}\text { Dar a manutenção necessária no equipamento, } \\
\text { instalando novos pontos de alarme nos locais } \\
\text { apropriados. }\end{array}$ \\
\hline 23. & \begin{tabular}{|l|} 
Apenas um banheiro utilizado \\
por todos exceto cadeirantes.
\end{tabular} & $\begin{array}{l}\text { Verificar e implantar } \\
\text { regulamentadoras de trabalho. }\end{array}$ \\
\hline 24. & $\begin{array}{l}\text { Coisas inúteis, pertences da } \\
\text { família e peças destinadas para } \\
\text { ferro velho são encontradas em } \\
\text { todos locais da empresa. }\end{array}$ & $\begin{array}{l}\text { Utilizar o senso de ordenação e utilização e } \\
\text { redesenhar o layout da empresa. }\end{array}$ \\
\hline 25. & $\begin{array}{l}\text { Acesso livre aos estoques e } \\
\text { ferramentas de alto valor. }\end{array}$ & $\begin{array}{l}\text { Manter estas ferramentas de alto valor em } \\
\text { local com chave evitando que fiquem com fácil } \\
\text { acesso. Estoques devem ficar em local único } \\
\text { com controle de acesso. }\end{array}$ \\
\hline 26. & $\begin{array}{l}\text { Local que no final da tarde às } \\
\text { vezes fica quase sem ninguém. }\end{array}$ & $\begin{array}{l}\text { Instalar sistema de filmagem na empresa em } \\
\text { local apropriado para que estes locais possam } \\
\text { ser monitorados, inibindo possíveis furtos. }\end{array}$ \\
\hline
\end{tabular}




\begin{tabular}{|c|c|c|}
\hline & Problema & Solução \\
\hline 27. & $\begin{array}{l}\text { Sala de espera utilizada também } \\
\text { por funcionários, utilizando } \\
\text { grande quantidade de copos } \\
\text { descartáveis. }\end{array}$ & $\begin{array}{l}\text { Destinar local próprio para funcionários } \\
\text { com armários para guardar pertences e } \\
\text { para utilizarem quando necessário evitando } \\
\text { desperdícios. }\end{array}$ \\
\hline 28. & \begin{tabular}{|lcrr} 
Móveis velhos & no & local \\
deixa o ambiente & um & pouco \\
desagradável & & \\
\end{tabular} & $\begin{array}{l}\text { Trocar móveis colocando alguns sejam mais } \\
\text { fáceis de limpar. }\end{array}$ \\
\hline 29. & $\begin{array}{l}\text { Cliente tem dificuldade de } \\
\text { escutar televisão na sala de } \\
\text { espera. }\end{array}$ & $\begin{array}{l}\text { Redesenhar o layout da empresa e levando em } \\
\text { conta isolação acústica para este local. }\end{array}$ \\
\hline 30. & $\begin{array}{l}\text { Dificuldade de atender clientes } \\
\text { no administrativo devido ao } \\
\text { excesso de barulho. }\end{array}$ & $\begin{array}{l}\text { Redesenhar o layout da empresa e levando em } \\
\text { conta isolação acústica para este local. }\end{array}$ \\
\hline 31. & 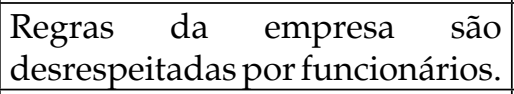 & $\begin{array}{l}\text { Colocar regras e cobrá-las caso elas sejam } \\
\text { descumpridas. }\end{array}$ \\
\hline 32. & $\begin{array}{l}\text { Local com cheiro de fumaça que } \\
\text { os carros largam. }\end{array}$ & $\begin{array}{l}\text { Instalar exaustores nos locais de manutenção de } \\
\text { veículos. }\end{array}$ \\
\hline 33. & $\begin{array}{l}\text { Ferramentas não são colocadas } \\
\text { em seus devidos lugares, } \\
\text { ficam espalhadas pelo chão e } \\
\text { ajuntadas pelo dono quando } \\
\text { acha necessário. }\end{array}$ & $\begin{array}{l}\text { Estipular lugares e exigir que as mesmas sejam } \\
\text { guardadas em seus devidos lugares por quem } \\
\text { as utilizou, utilizando o senso de limpeza e } \\
\text { utilização. }\end{array}$ \\
\hline
\end{tabular}

Fonte: Elaborado pela autora.

\section{CONSIDERAÇÕES FINAIS}

Durante a realização deste estudo, a equipe de trabalho da empresa se mostrou muito receptiva e disposta a colaborar com o estudo em questão. Com o apoio de todos da empresa, o propósito deste trabalho foi alcançado, melhorias no ambiente e até mesmo nos processos foram realizados pelos gestores no desenvolver deste estudo. Visivelmente observou-se nestas mudanças economia de tempo, dinheiro e um atendimento mais satisfatório a seus clientes, além de uma melhor organização na empresa. As sugestões deste estudo ficam a cargo dos gestores a sua implantação.

Outras melhorias poderiam ser sugeridas através de um estudo mais profundo e detalhado em outros processos, os quais este estudo não abrange. É de suma importância que os gestores analisem os processos da empresa para que os mesmos possam ser melhorados com o intuito de melhorar o atendimento aos clientes, fornecedores e entregadores a fim de melhorar as finanças da empresa em questão. 


\section{REFERENCIAS}

BARROS, Mariana. Frota brasileira cresce onze vezes mais rápido do que a população e já é suficiente para cobrir Barbados, no Caribe. Revista Veja, São Paulo, 12 fev. 2015. Disponível em: http:/ / veja.abril.com.br/blog/cidades-sem-fronteiras/transporte-etransito/frota/. Acesso em 20 abr. 2016.

BROCKE, Jan Von; ROSEMANN, Michael. Manual de BPM gestão de processos de negócio. São Paulo: Bookman, 2013. E-book. Disponível em: < https:/ / books.google. com.br/books?id=A846AgAAQBAJ\&pg=PA1\&dq=conceito+gest $\%$ C3\%A3o+de+pro cessos\&hl $=$ pt-BR\&sa $=X \&$ redir_esc $=y \# v=$ onepage $\& q=$ conceito $\% 20$ gest $\% C 3 \% A 30 \% 20$ de\%20processos\&f=false $>$. Acesso em: 25 abr. 2016.

CORRÊA, Vanderlei Moraes; BOLETTI, Rosane Rosner. Ergonomia: fundamentos e aplicações. Porto Alegre: Bookman, 2015.

COSTA, Fábio J. C. L. Introdução a administração de materiais e sistemas informatizados. 2002. E-book. Acesso em: < https://books.google.com.br/books?i $\mathrm{d}=4$ POWILFn6uUC\&pg=PA56\&dq=importancia +do+cadastro+de+clientes\&hl=pt$\mathrm{BR \& sa}=X \&$ redir_esc $=\mathrm{y} \# \mathrm{v}=$ onepage \&q\&f=false $>$. Acesso em: 06 mai. 2016.

CUSTODIO, Marcos F. (Org.). Gestão da qualidade e produtividade. São Paulo: Pearson Education do Brasil, 2015. E-book. Disponível em: <http://univates.bv3. digitalpages.com.br/users/publications/9788543010120/pages/-8>. Acesso em: 22 abr. 2016.

CHIAVENATO, Idalberto. Administração da produção: uma abordagem introdutoria. Rio de Janeiro: Elsevier, 2005.

DE SORDI, José Osvaldo. Gestão por processos: uma abordagem da moderna administração. 2. ed. rev. atual. São Paulo: Saraiva, 2009.

IIDA, Itiro. Ergonomia: projeto e produção. São Paulo: Edgard Blucher, 2000.

LUCINDA, Marco A. Qualidade: fundamentos e prática para cursos de graduação. Rio de Janeiro: Brasport, 2010. E-book. Disponível em: <https:/ /books.google.com. br/books?id=e9Baz6Jxh3MC\&pg=PA33\&dq=gest $\%$ C3\%A3o+de+processos\&hl =pt-BR\&sa=X\&redir_esc $=y \# v=$ onepage \&q=analise $\% 20 \mathrm{e} \% 20$ melhoria $\% 20 \mathrm{de} \% 20$ processos\&f=false $>$. Acesso em: 28 abr. 2016.

MALHOTRA, Naresh K; ROCHA, Ismael; LAUDISIO, Maria Cecilia. Introdução a pesquisa de marketing. São Paulo: Prentice Hall, 2005.

MARQUES, Cicero F. Estratégia de gestão da produção e operações. Paraná: IESDE Brasil: 2012. E-book. Disponível em: <https://books.google.com.br/books?id=CgDaYiaAZAC\&pg=PA60\&dq=arranjo+f\%C3\%ADsico\&hl=pt-BR\&sa=X\&redir esc $=\mathrm{y} \# \mathrm{v}=$ onepage $\& \mathrm{q}=$ arranjo $\% 20 \mathrm{f} \% \mathrm{C} 3 \% A D$ sico\&f=false $>$. Acesso em: 30 abr. 2016.

MARQUES, Wagner L. Administração de logística. Paraná: Cianorte, 1994. E-book. Disponível em: https:/ /books.google.com.br/books?id=UAn9zkToc58C\&pg=PA51\& 
$\mathrm{dq}=\operatorname{arranjo}+\mathrm{f} \% \mathrm{C} 3 \% \mathrm{ADsico} \& \mathrm{hl}=\mathrm{pt}-\mathrm{BR} \& \mathrm{sa}=X \&$ redir_esc $=\mathrm{y} \# \mathrm{v}=$ onepage $\& \mathrm{q}=\operatorname{arranjo} \% 20$ f\%C3\%ADsico\&f=false. Acesso em: 30 abr. 2016.

MARQUES, Wagner L. Diário de um empreendedor: a real informação para os gestores de sucesso. 1. ed. Paraná: Cianorte, 1994. E-book. Disponível em: < https:/ / books.google.com.br/books?id=LQ8r2j_rjQ4C\&pg=PA62\&dq=o+que +\%C3\%A9++um+fluxo+de+caixa+para+as+empresas\&hl=pt-BR\&sa=X\&redir esc $=y \# v=$ onepage $\& q=0 \% 20$ que $\% 20 \%$ C3 $\% A 9 \% 20 \% 20$ um $\% 20$ fluxo $\% 20$ de $\% 20$ caixa $\% 20$ para $\% 20$ as $\% 20$ empresas $\& \mathrm{f}=$ false $>$. Acesso em: 05 mai. 2016.

OLIVER, Paulo R. C. Projeto de ECM/BPM: os segredos da construção. São Paulo: Biblioteca 24 horas, 2010. E-book. Disponível em: < https:/ / books.google.com.br/bo oks?id=74AoyYcbURgC\&pg=PA122\&dq=an $\%$ C3\%A1lise+e+melhoria + de + processos $\&$ hl $=$ pt-BR\&sa $=X \&$ redir_esc $=y \# v=$ onepage \&q $=a n \% C 3 \% A 1 l i s e \% 20 \mathrm{e} \% 20$ melhoria $\% 20$ de\%20processos\&f=false $>$. Acesso em: 28 abr. 2016.

PAIM, Rafael; CARDOSO, Vinícius; CAULLIRAUX, Heitor. Gestão de processos: pensar, agir e aprender. São Paulo: Bookman, 2009.

PEREIRA, Maurício Fernades. Modelo de produção de material didático: o uso da notação BPMN em cursos a distância. Revista de Administração e Inovação, São Paulo, v. 8, n. 4, out./dez. 2011. Disponível em: <www.revistas.usp.br/rai/article/ download/79237/83309>. Acesso em: 29 abr. 2016.

REIS, Thiago. Com aumento da frota, país tem 1 automóvel para cada 4 habitantes. G1, São Paulo, 10 mar. 2014. Disponível em: <http:/ /g1.globo.com/brasil/noticia/2014/03/comaumento-da-frota-pais-tem-1-automovel-para-cada-4-habitantes.html>. Acesso em: 20 abr. 2016.

SANTOS, Franklin. Contabilidade pública. 1. ed. Recife: Ed. Clube dos Autores, 2012. E-book. Disponível em: <https://books.google.com.br/books?id=hHAuBQAAQB AJ\&pg $=$ PA131\&dq $=$ estoque + minimo $+\mathrm{e}+\mathrm{m} \% \mathrm{C} 3 \% \mathrm{~A} 1 \mathrm{ximo} \& \mathrm{hl}=\mathrm{pt}-\mathrm{BR} \& \mathrm{sa}=\mathrm{X} \&$ redir esc $=\mathrm{y} \# \mathrm{v}=$ onepage $\& \mathrm{q}=$ estoque $\% 20 \mathrm{minimo} \% 20 \mathrm{e} \% 20 \mathrm{~m} \% \mathrm{C} 3 \% \mathrm{~A} 1 \mathrm{ximo} \& \mathrm{f}=$ false $>$. Acesso em: 05 mai. 2016.

SILVA, Joao Martins da. 5S: o ambiente da qualidade. 4. ed. Belo Horizonte: Fundação Christiano Ottoni, 1994.

SISP. Fluxo da metodologia. Disponível em: < http:/ / www.sisp.gov.br/mgpsisp/ processos/Surgimento\%20de\%20novos\%20projetos.htm\#6c668373-789f-4be8-b78e6c504ea9b726>. Acesso em: 22 abr. 2016.

VIEIRA, Augusto Cesar Gadelha. Manual do layout: arranjo físico. Rio de Janeiro: CNI, 1976.

STADLER, Adriano (Org.). Gestão de Processos com Suporte em Tecnologia da Informação. Curitiba: InterSaberes, 2013. E-book. Disponível em: <http:/ / univates. bv3.digitalpages.com.br/users/publications/9788582127780/pages/5>. Acesso em: 22 abr. 2016.

VERGARA, Sylvia Constant. Projetos e relatórios de pesquisa em administração. 12. ed. São Paulo: Atlas, 2010. 